\title{
Court orders DNA test over chemical claims
}

San Francisco. A Californian court commissioner has ordered a mentally handicapped child to undergo a DNA test in what is believed to be the first use of screening technology as part of a lawsuit over workplace safety in the United States.

The court order coincides with the passage through the California state legislature of a bill designed to prohibit health insurance companies from using genetic information to identify clients with a potential risk or to raise insurance premiums.

In the case in question, lawyers defending KTI Chemicals Inc. had requested both the DNA test and a chromosome analysis of Darryl Severson. The lawsuit against the firm was filed by LeAnn Severson on her son's behalf.

Mrs Severson says her child was permanently damaged as a result of her exposure to KTI's solvents while she assembled silicon wafers. But lawyers acting for the company argue that Darryl suffers from Fragile-X syndrome.

Fragile-X syndrome is the most common cause of inherited mental retardation, and is the result of an increase in the number of CGG repeats in a gene carried on the $\mathrm{X}$ chromosome. The number of repeats correlates with the degree of mental retardation

and usually increases from one generation to the next. Males are more commonly affected than females, with only a third of female carriers suffering some degree of intellectual handicap themselves.

According to court documents, the Seversons are asking for $\$ 5.6$ million for Darryl's suffering and the costs of his care, education and medical treatment.

The decision to turn to DNA testing to help resolve the argument has alarmed some geneticists, who believe such uses take DNA testing far beyond its present capabilities. Paul Billings, an associate clinical professor of medicine at Stanford University, warns that although genetic information is only one component of any particular human trait or illness, society's emphasis on gene discovery and technology means that DNA testing may carry undue weight when used in courtrooms and other social settings.

Testing for Fragile-X syndrome can detect the number of $\mathrm{CGG}$ repeats in the gene linked to Fragile-X. If Darryl Severson has an increased number of CGG repeats, it will not prove that his retardation has a genetic origin: more than 13 per cent of boys with the Fragile- $X$ genetic marker show no retardation at all because they have an intermediate number of repeats, and are classed as

\section{Trials 'must compete for new funds'}

Washington. In an unusual move, the $\mathrm{Na}$ tional Cancer Institute (NCI) announced last week that the National Surgical Adjuvant Breast and Bowel Project (NSABP) will have to compete openly next year for a grant to continue running clinical trials investigating treatment methods for breast and bowel cancer

The NSABP, based at the University of Pittsburgh, has come under fire in recent months for administrative failures in its data monitoring. At the end of March, the NCI asked the University of Pittsburgh to replace Bernard Fisher as the group's principal investigator because of its concern over the way that the project was being run.

NSABP would normally have had to submit a proposal in 1996 to continue in its role as coordinator of large-scale clinical trials. At the request of the NCI, a panel of scientific counsellors last week recommended that a new proposal should be submitted a year earlier, and in competition with other groups.

"It is unusual to have an open competition, but the NSABP has generated so much concern that it seemed needed," says Clara Bloomfield, chair of the panel and head of the department of medicine at Roswell Park Cancer Institute.

If coordinating groups such as the NSABP are not awarded a continuation of their grant, the clinical trials they run are phased out over a year. To allay concern that the current tamoxifen breast cancer prevention trial would close if the NSABP failed in a competition, the NCI has said that it would take over the trial itself in such circumstances.

Meanwhile the controversy over the NSABP's monitoring of data continued in Congress last week at a hearing chaired by Representative John Dingell (Democrat, Michigan). Various witnesses from the NCI, Zeneca (the manufacturers of tamoxifen), and the University of Pittsburgh attempted to placate Dingell's wrath at the way the NSABP has managed its trials.

Bernard Fisher, accompanied by his lawyer, was among the witnesses. Fisher, a pioneer in the treatment of breast cancer, apologized for not acting faster once falsified data in a trial evaluating the relative effectiveness of different treatments of breast cancer had come to light.

The falsified data appeared in a trial comparing lumpectomy followed by radiation therapy with mastectomy for women with early breast cancer. A re-analysis by the NCI showed that the falsified data did not alter the finding that lumpectomy followed by radiation therapy was an effective treatment for some women. Helen Gavaghan being in the pre-mutation range. They may have learning disabilities and behavioural problems. But such a result would cast doubt on Severson's claim that toxic exposure hurt her son.

KTI argues that the chemicals in question cannot cause irreversible birth defects. The company's lawyers based their demand for a DNA test on the defendant's right to show 'alternative cause', arguing that all possible evidence should be explored to assess whether there was a chemical, genetic or some other cause for the retardation.

Once the lawyers have been provided with a sample of Darryl's blood, they may carry out additional genetic testing and search for another chromosomal explanation.

The DNA test was ordered as part of pretrial motions. Earlier this month, lawyers for the Seversons filed a challenge to the order. Mrs Severson argues that the test is an invasion of Darryl's privacy.

Fragile-X testing has already come under fire in other arenas, reflecting concern that use of genetic testing technology may be outpacing its helpfulness. In one widely cited example, researchers have screened children in public schools in Denver, Colorado for Fragile-X syndrome, even though there is no known treatment specifically for the condition.

The case has sparked controversy because children already in special education programmes were selected for the DNA test on the basis of their behavioural and physical characteristics, potentially marking the students as genetically impaired before any DNA was examined. The director of the study, Randi Hagerman, a professor of paediatrics at the University of Colorado, is an expert witness for KTI in the Severson case.

So far, the Denver study has found five cases of Fragile-X and three cases of other sex chromosome abnormalities after screening 400 students. Hagerman claims that identifying boys with the syndrome helps to optimize the treatment and education they receive, and provides an opportunity for reassurance and genetic counselling for families. According to Hagerman, researchers are already considering proposing Fragile$\mathrm{X}$ testing in the general population because the condition is so common.

Hagerman said it was a medical necessity to test for Fragile- $X$ in cases of mental retardation where some physical characteristics of the syndrome are present. In Darryl Severson's case, she said, it was important to rule out the most common medical causes of mental retardation.

But if the test does show that Darryl has an increased number of repeats, the lawyers and their experts are likely to engage in a bitter dispute over how much it may have contributed to his condition.

Sally Lehrman 